Esta publicación cientifica en formato digital es continuidad de la revista impresa ISSN-Versión Impresa 0798-1406 / ISSN-Versión on line 2542-3185Depósito legal pp
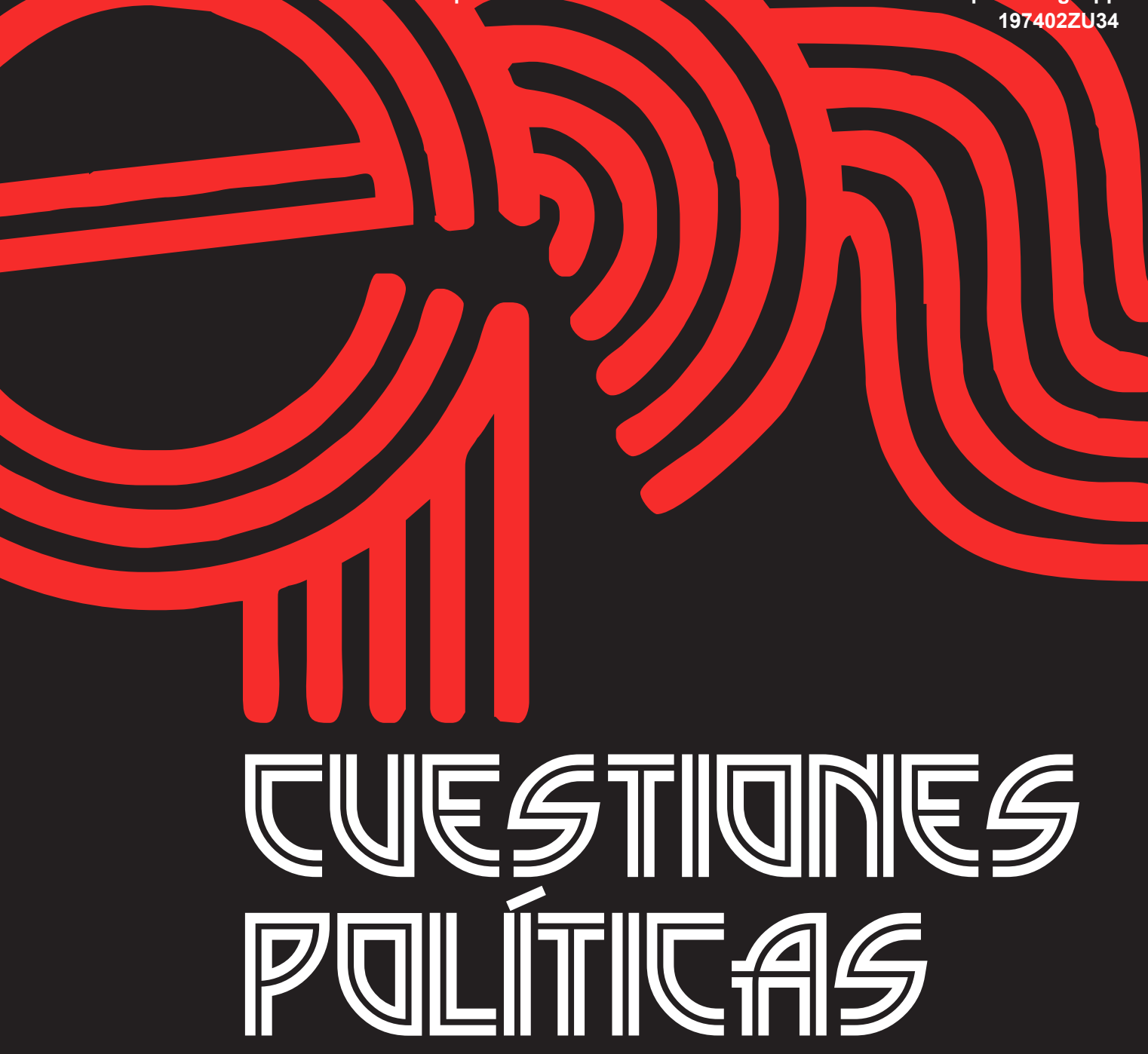

Instituto de Estudios Políticos y Derecho Público "Dr. Humberto J. La Roche" de la Facultad de Ciencias Jurídicas y Políticas de la Universidad del Zulia Maracaibo, Venezuela
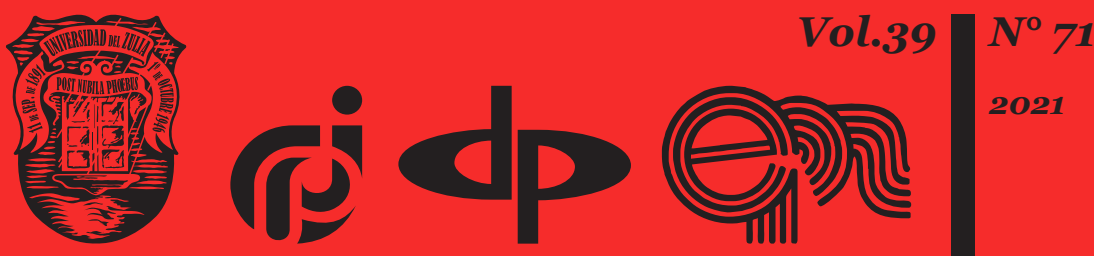


\title{
Legal features of the use of big data in the tax activities of the state
}

\author{
DOI: https://doi.org/10.46398/cuestpol.3971.43
}

\author{
Dmitriy Anatolyevich Smirnov * \\ Leila Emerbekovna Botasheva ** \\ Razela Nesyurovna Denikaeva *** \\ Alexey Nikolaevich Leonov ***** \\ Evgeny Anatolievich Pervyshev *****
}

\begin{abstract}
Objective: The article is devoted to determining the legal nature of Big Data technology. Some aspects of the problematic in the field of using Big Data technology in public tax activities are investigated. The theoretical and legal approaches to the regulation of Big Data technology in domestic and international law are analyzed. Methods: The authors used a combination of methods: theoretical, general scientific methods and empirical methods. Results: The development of the conceptual and terminological apparatus and the harmonization of domestic and international legislation is indicated as one of the possible directions for the formation of legislation. Conclusion and recommendations: Active implementation of the activities of tax authorities in the digital economy requires the adoption of adequate legal decisions. The thesis that legislation must be formed considering the legal and commercial nature of Big Data technology is considered. The use of Big Data technology must be accompanied by legal and ethical standards.
\end{abstract}

Keywords: Big Data; tax activities, personal information; legal regime, information security.

\footnotetext{
* North Caucasus Federal University, Russia. ORCID ID: https://orcid.org/oooo-0oo2-8300-0828

** North Caucasus Federal University, Russia. ORCID ID: https://orcid.org/oooo-0oo1-7704-2960

*** North Caucasus Federal University, Russia. ORCID ID: https://orcid.org/oooo-00o2-0662-9470

**** North Caucasus Federal University, Russia. ORCID ID: https://orcid.org/oooo-0001-5007-5172

****** North Caucasus Federal University, Russia. ORCID ID: https://orcid.org/oooo-0oo1-7799-6107

Recibido el 14/08/2021

Aceptado el 15/10/2021
} 
Dmitriy Anatolyevich Smirnov, Leila Emerbekovna Botasheva, Razela Nesyurovna Denikaeva, Alexey Nikolaevich Leonov y Evgeny Anatolievich Pervyshev

716

Legal features of the use of big data in the tax activities of the state

\section{Características legales del uso de big data en las actividades fiscales del estado}

\section{Resumen}

El artículo está dedicado a determinar la naturaleza jurídica de la tecnología Big Data. Se investigan algunos aspectos de la problemática en el campo del uso de la tecnología Big Data en la actividad tributaria pública. Del mismo modo, se analizan los enfoques teóricos y legales de la regulación de la tecnología Big Data en el derecho internacional. Los autores utilizaron una combinación de métodos: teóricos, métodos científicos generales y métodos empíricos. El desarrollo del aparato conceptual y terminológico y la armonización de la legislación rusa e internacional se señala como una de las posibles orientaciones para la formación de la legislación. En las conclusiones y recomendaciones se muestra que la implementación activa de las actividades de las autoridades tributarias en la economía digital requiere la adopción de decisiones legales adecuadas. Se plantea la tesis de que la legislación debe formarse teniendo en cuenta el carácter legal y comercial de la tecnología Big Data. El uso de la tecnología Big Data debe ir acompañado de estándares legales y éticos.

Palabras clave: Big Data; actividades fiscales; información personal; régimen legal, seguridad de la información

\section{Introduction}

The editor of the scientific journal Nature, Clifford Lynch, introduced the concept of Big Data over twelve years ago, noting that digital information has overtaken oil as the most valuable commodity in the world. Big data is new oil; this similarity is determined not only by value. Raw data arrays are just as of little use as raw oil, and companies that "extract" data quickly become the most profitable in the world (Sosnin, 2019). Clifford Lynch, having discovered the Big Data phenomenon, proposed using this term by analogy with the metaphorical expression "big oil" that is similar in the English-speaking business environment (Lynch, 2008). It is indisputable that today, data in conjunction with modern technologies for their analysis modify economic, political, and legal relations.

The active digitalization of the economy has a direct impact on the tax activity of the state, which is defined as "... the activity of the state in organizing taxation and ensuring its implementation in order to meet its need for funds" (Khudyakov, 1995: 55). Tax activity of the state in the most simplified version is defined as the activity of the state in establishing, imposing and collecting taxes and fees. 
The key point in defining public tax activities is public fiscal interest. Now public tax activity reflects the connection between the state, the economy, public financial interests and needs.

In the context of the digitalization of the economy, public administration, and society, it is important to determine the priorities, forms and boundaries of legal regulation, transformed and awaiting further transformation, taking into account the use of information technologies.

Digitalization processes also have their drawbacks, primarily due to the risk of disclosing personal information, information, in addition to speed, efficiency, accessibility and a number of other advantages.

World trends in the digital transformation of the financial activities of the state are manifested in the following: open development in government departments and IT departments; open government data; machine readable laws; websites of public authorities; development of digital administrative codes; building a community of government IT developers; involvement of $\mathrm{CDO}$ (Chief Data Officer) specialists - the main ones in terms of data quality, policy of their formation and implementation of data-based solutions; training and retraining (Botasheva, 2018).

Today, there is a lot of incomprehensible for lawyers in the field of new information technologies. There are more questions than answers in attempts to regulate digital relations arising, including in the financial sphere. Nevertheless, the future lies in advanced digital technologies, and therefore the need to clarify the legal essence and use Big Data in state tax activities in the digital economy will only grow and become more relevant.

\section{Methodology}

Analysis of publications shows that today there is no comprehensive scientific research devoted to the use of Big Data in public activities of the state in the formation, distribution, and organization of the use of state funds. In modern conditions of development of the digital economy, which creates the vulnerability of the legal regime of confidentiality of personal data, consideration of the legal protection of personal financial data is required.

The methodological basis for the development and implementation of legal instruments for regulating Big Data in the activities of bodies engaged in financial activities is a set of research methods: theoretical methods analysis and study of regulatory acts that determine the implementation and development of Big Data technology; theoretical analysis and synthesis, analysis of the status of legal regulation of Big Data in Russia and the world, methods of inference; general scientific methods - modeling of possible 


\section{Dmitriy Anatolyevich Smirnov, Leila Emerbekovna Botasheva, Razela Nesyurovna Denikaeva, Alexey Nikolaevich Leonov y Evgeny Anatolievich Pervyshev \\ Legal features of the use of big data in the tax activities of the state}

options for legal regulation of Big Data technology, analysis, synthesis, generalization, systematization, classification; empirical methods observation, survey methods, monographic studies, methods of statistical processing and qualitative analysis of the results of scientific research.

\section{Results}

Regulation of the Big Data technology in the domestic regulatory environment should be formed based on a balance between the principle of formal certainty of legal norms, on the one hand, and technological development, on the other (Arkhipov and Naumov, 2016). The definition of Big Data should be interpreted in a uniform manner to ensure consistent and predictable application of the law, which at the moment is not reliable.

Big data requires independent consolidation in the current legislation, different from the definition of personal data. The legislator needs to develop new basic principles for the application of Big Data, based on their versatility, innovation and commercial nature.

The digital economy is a data economy. Big data promises big socially acceptable and desirable benefits in state financial activity (Silva, 2019). Digital information has overtaken oil as the most valuable commodity in the world. Big Data technology is inherently global and limitless; the study showed a lack of uniform international norms and agreements regarding which standards should govern the use of Big Data. To fill this gap, it is important to adopt unified international agreements based on international human rights law. International standards should contain legal and ethical restrictions for the global commercial use of Big Data technologies.

\section{Discussions}

One of the main tasks of the national program "Digital Economy of the Russian Federation" is to ensure favorable conditions for the collection, processing, and storage of data. Humanity is at a new stage in its development, which is seen as the fourth industrial revolution; and modern statistics show that the amount of generated data is constantly growing. According to expert estimates, the global data volume can reach 163-175 zettabytes by 2025 (this figure was $33 \mathrm{ZB}$ in 2018), and their analysis becomes a tool for making effective decisions in the field of public administration, improving the quality of public services provided, adjusting production and business processes (Shuvalova, 2019).

Big data refers to the amount of information that cannot be processed by traditional methods, that is, using a conventional computer in a short time. 
Special software and infrastructure - data centers, a network is needed to work with them. Big Data technology solutions are equipment kits, software and service kits.

The term "Big Data" does not have a universally accepted definition in both jurisprudence and the information technology industry. A.I. Savelyev, Senior Research Fellow at the Higher School of Economics National Law University's Information Law Research Laboratory, defines Big Data as a set of tools and methods for processing massive and structured and unstructured data from various sources subject to constant updates in order to increase the quality of managerial decision making, creating new products and increasing competitiveness (Savelyev, 2015). The above definition reflects, in our opinion, the legal nature and practical significance of Big Data.

Big Data technologies are universal in nature and can be used in various fields of financial activity. The potential advantages of using Big Data in the financial activities of the state are carried out both in imperative relations, mediating the participation of the state in the financial activities of the state; these are budgetary, tax relations, relations in the field of state insurance and state credit, as well as dispositive financial relations, which include credit, settlement, insurance, investment, stock relations (Nefedov, 2013).

Central banks see the benefits of using big data as a potentially effective forecasting tool to support analysis of macroeconomic and financial stability. An analysis of monetary policy can benefit from better and more timely forecasts of macroeconomic indicators for the near future; it may be useful for macro and micro prudential policies. The development of technologies for processing and analyzing gigantic amounts of data today determines the future of tax administration.

The information system of the Federal Tax Service of Russia today stores and uses information from 4.8 million legal entities and 3.6 million existing individual entrepreneurs. At the same time, the volume of the documents presented by them only on VAT returns is about $2 \mathrm{~Tb}$. In addition, the Federal Tax Service of Russia aggregates and uses information received from other departments; About one billion records come to tax authorities per year (Matveeva, 2016).

There is a resonant bill "On a unified federal information register containing information about the population of the Russian Federation." The specified register will contain a huge array of data, more precisely, more than 30 types of information about a person - in particular, name, date and place of birth, gender "and another gender if it changes", marital status, citizenship, information about registration with the tax authority , including as a taxpayer of the tax on professional income, information on registration as an individual entrepreneur, on military registration, 
Dmitriy Anatolyevich Smirnov, Leila Emerbekovna Botasheva, Razela Nesyurovna Denikaeva, Alexey Nikolaevich Leonov y Evgeny Anatolievich Pervyshev

registration in the systems of compulsory health insurance, social insurance and the pension system, documents on education / study, qualifications, awards, deprivation, restoration of an academic degree / title, information about parents / children, date and place of death.

It is not clear from the provisions of the bill how the information security of the system will be ensured, because the data stored in it is of great value for commercial use. In the era of Big Data (Big Data), one cannot ignore the commercial value of the information that will be included in a single information register. The question of the legal definition of Big Data remains open, which causes uncertainty in the understanding of personal data and their differentiation from Big Data.

The unified federal information register falls under the jurisdiction of the Federal Tax Service, which raises a lot of questions and indicates the priority of fiscal, public interests to the detriment of private interests. Since we are talking about personal information, the issues of ensuring privacy and protecting the rights of subjects of personal data should be dominant and decisive.

The obvious imperativeness of the provisions of the bill raises many questions, indicating a bias towards ensuring public interests. The compulsory nature of the processing of personal information about an individual, from the moment of birth to information about the date of death. An individual should not be deprived of the right to prohibit the use of his own data. Just as in the case of the processing of personal data, it is necessary to provide for the consent of an individual.

The reliability of information, methods and means of providing it raises many questions. It also does not provide for the possibility of an individual checking the reliability of his information.

However, the global problem is the lack of an independent normative act regulating Big Data. Most countries, including EU countries, regulate their personal data protection laws and are subject to the GDPR (General Data Protection Regulation). The GDPR provides for the creation of a European Data Protection Board, a European Inspector for Personal Data Protection. There is centralized control over the application of the provisions of the law, as well as uniformity of policy in the EU.

In our opinion, the existence of a supervisory authority is a situation that deserves the attention of the Russian legislator, since the activities of the Federal Service for Supervision in the Sphere of Telecommunications of the Russian Federation, Information Technologies, and Mass Communications, covering only personal data, leaving Big Data without legal protection mechanisms (Politou et al., 2019; Dautova, 2019). 
The lack of separate independent regulation of Big Data is compensated in the European Union by the presence of an extensive interpretation of personal data, including the definition of an IP address. It should also be noted that in addition to the general provisions of the GDPR, the rules regarding profiling apply. "Profiling" means "any form of automated data processing for the purpose of analyzing and making assumptions about various personal characteristics of an individual, in particular, his performance, creditworthiness, economic situation, location, health, taste preferences and behavior" (Article 4 (4) GDPR) (HSE university, 2018).

The definition of Big Data as arrays of information, the source of which are various channels with a high transmission rate, are mentioned in the Big Data Policy of the European Commission (Sosnin, 2019). Moreover, data can be either created by people or generated by computers.

Because Big Data is primarily the personal data of the user; It should be noted that the EU has positive experience in collecting certain types of information in the provision of online services, in particular cookies. The processing of cookies by users of online services is regulated by Directive $2002 / 58$ / EC on the protection of privacy and electronic communications (e-privacy Directive).

The provisions and experience of the European Union should play a legal role in the regulation of Big Data, since Big Data has a high potential for the economy and financial activities of the state. The next important stage in the development of technology should be the task of creating modern legal tools that meet the requirements of the existing experience of individual countries, including the European Union.

\section{Conclusions and recommendations}

The process of updating the tax law is now being observed. Modern technologies provide fundamentally new opportunities, tax law is also experiencing their impact. On the one hand, the technological process and digitalization create opportunities for increasing the efficiency of tax mechanisms, on the other hand, such innovations can be interpreted as new challenges for tax regulation. These challenges include: the balance of public and private interests, protection of information and personal data.

Big Date in tax activities can be used primarily in fiscal interests for forecasting, making decisions in tax administration, assessing the positive and negative consequences of these decisions, and determining previously hidden dependencies. Unfortunately, it should be noted that today the tax service is only able to store data and deliver it upon request, without using the huge potential inherent in the data that the Federal Tax Service of the Russian Federation has at its disposal. 
Dmitriy Anatolyevich Smirnov, Leila Emerbekovna Botasheva, Razela Nesyurovna Denikaeva, Alexey Nikolaevich Leonov y Evgeny Anatolievich Pervyshev

Tax activity in the digital economy, capable of providing high-quality information and communication infrastructure and mobilizing the capabilities of information and communication technologies for the benefit of taxpayers, business and the state, must undoubtedly transform and change. The digital economy is a form of economic activity that emerges from billions of examples of the networking of people, businesses, devices, data and processes.

"The Strategy for the Development of the Information Society in the Russian Federation for 2017-2030" determines that the digital economy is an economic activity in which the key factor in production is digital data, the processing of large volumes and the use of the analysis results of which, compared with traditional forms of management, can significantly increase the efficiency of various types of production, technologies, equipment, storage, sales delivery of goods and services.

The digital economy is based on hyper-connectivity, i.e., the growing interconnectedness of people, organizations, and machines, emerging thanks to the information and telecommunications network Internet, mobile technologies and the Internet of things. The industry of tax law and legislation will have to face all the consequences of digitalization, which are already generating fundamental changes in the models of economic and financial activity in leading countries. Digitalization should make the taxation activities of the state more open.

The digitalization of government tax activities leads to the accumulation of a huge array of tax and financial data, which is used either to provide consumers with new financial services or to increase authority through automatic compliance checks. The term "digitalization" is steadily associated with Big Data. Modern policy is developing towards ensuring openness and transparency of data in the financial sector, requiring public authorities to publish "open data" on official websites. This position is unconditionally rational, since the entire digital economy is a data economy, but so far, the issues of financial and tax confidentiality remain open. The right to financial and tax confidentiality continues to be illusory.

The extensive collection and use of "large" tax and financial data seriously violates data privacy and protection, especially when these data are used in smart algorithms to create digital personal profiles or to make automatic decisions that can only affect people. Ultimately, this practice of profiling tax and financial behavior creates a fertile ground for discriminatory treatment of individuals and groups.

The conclusion is substantiated that it is necessary to introduce a norm for mandatory publication of information on leaks, compensation payments and large penalties to bodies carrying out financial activities as the most effective mechanism of self-regulation, in which a sense of security policy 
appears, i.e., motivation to comply with the social responsibility of state authorities for the security of Big Data.

\section{Bibliographic References ${ }^{6}$}

ARKHIPOV, Vladislav; NAUMOV, Victor. 2016. "The legal definition of personal data in the regulatory environment of the Russian Federation: Between formal certainty and technological development” In: Computer Law \& Security Review. Vol. 32, No. 6, pp. 868-887.

BOTASHEVA, Leila E. 2018. "Information function of "Civic budget" In: International Journal of Law and Management. Summer. Vol. 3, pp. 100-112.

DAUTOVA, Elvira. 2019. Regulation of Big Data: The Economic and Legal Aspect. 2019. Available online. In: https://zakon.ru/blog/2019/04/29/ regulirovanie_bolshih_dannyh_ekonomiko-pravovoj_aspekt. Date of consultation: 10/01/2021.

HSE UNIVERSITY. Regulation of the Use of Big Data and User Data in the EU. 2018.

SILVA, Jesus. 2019. "Privacy Preserving, Protection of Personal Data, and Big Data: A Review of the Colombia Case" In: Procedia Computer Science. Vol. 151, pp. 1213-1218.

KHUDYAKOV, A. 1995. Financial Law of the Republic of Kazakhstan: (General Part). Almaty, Kazakhstan.

LYNCH, Clifford. 2008. "Big data: How do your data grow?" In: Nature. Vol. 455 , No. 7209 , p. 455.

MATVEEVA, T.V. 2016. The Federal Tax Service is already using Big Data technologies in tax administration. Available online. In: https://www. nalog.ru/rn77/news/activities_fts/5979856/. Date of consultation: 10/01/2021.

NEFEDOV, D. 2013. Financial law: teaching aid. Izd-vo Politekhnicheskogo unta. St. Petersburg, Russia.

POLITOU, Eugenia; ALEPIS, Efthimios; PATSAKIS, Constantinos. 2019. "Profiling tax and financial behaviour with big data under the GDPR" In: Computer Law \& Security Review. Vol. 35, No. 3, pp. 306-329.

6 Some cited sources only have the initial of the name of the author or authors because it was impossible to locate their full name as stable the standard of this journal. 
Dmitriy Anatolyevich Smirnov, Leila Emerbekovna Botasheva, Razela Nesyurovna Denikaeva, Alexey Nikolaevich Leonov y Evgeny Anatolievich Pervyshev

SAVELYEV, Aleksandr. 2015. "Problems of the application of the legislation "On personal data" in the era of Big Data. Law" In: Journal of the Higher School of Economics. No. 1, pp. 43-66. Available online. In: https://lawjournal.hse.ru/data/2015/04/20/1095377106/Savelyev.pdf. Date of consultation: 10/01/2021.

SHUVALOVA, Maria. 2019. Data management in the transition to a digital economy. Available online. In: http://www.garant.ru/ article/1263975/\#ixzz6Guzn9gzn. Date of consultation: 10/01/2021.

SOSNIN, Kirill. 2019. "Legal Regulation of Big Data: Foreign and Domestic Experience" In: Journal of the Intellectual Property Court. Vol. 35, pp. 30-42. Available online. In: http://ipcmagazine.ru/legal-issues/ legal-regulation-of-big-data-foreign-and-domestic-experience. Date of consultation: 10/01/2021. 

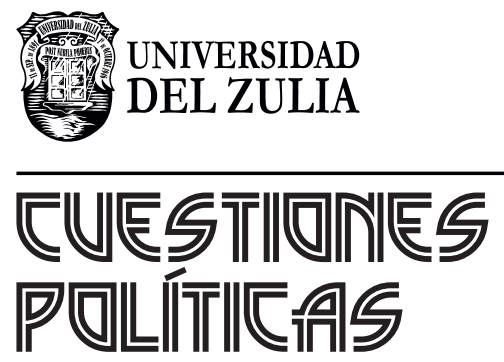

Vol. 39 N $^{\circ} 71$

Esta revista fue editada en formato digital y publicada en diciembre de 2021, por el Fondo Editorial Serbiluz, Universidad del Zulia. Maracaibo-Venezuela 